\title{
ХРОН ИКА
}

\section{WORKSHOP: THE MONGOLS AND THE SILK ROADS (MAY 10-11, 2018, FACULTY OF ARTS, UNIVERSITY OF SZEGED)}

\author{
Aleksandar Uzelac \\ The Institute of History Belgrade \\ Belgrade, Serbia \\ aleksandar.uzelac@iib.ac.rs
}

\begin{abstract}
On May 10-11 2018, the Faculty of Arts of the University of Szeged hosted an annual gathering of researchers dealing with the history of the Mongol Empire. The event was organized by several members of the Turkological Research group of MTASZTE ("Hungarian Academy of Sciences - University of Szeged"). Its main goal was the reassessment of a role that the international networks of merchants, and their activities along the Silk Roads, played in the Mongol Empire. The event saw the gathering of eleven participants from Hungary, United Kingdom, Germany, Bulgaria, Serbia, Israel, China and Japan, who covered a wide range of topics and source materials. The working language was English.

On the first day, István Vásáry, professor emeritus of Eötvös Loránd University and keynote speaker of the event, held his lecture: The Mongol Period: Heyday of the Silk Roads. The other participants' presentations, divided into four sessions, and followed by long, exhaustive and fruitful discussions, took place the next day. The presented papers will be published in one of the volumes of the internationally recognized journal Acta Orientalia Academiae Hungaricae in 2019.
\end{abstract}

Keywords: Mongol Empire, Silk Roads, Golden Horde, international workshop, Turkological Research group of MTA-SZTE

For citation: Uzelac A. Workshop: The Mongols and the Silk Roads (May 10-11, 2018, Faculty of Arts, University of Szeged). Zolotoordynskoe obozrenie $=$ Golden Horde Review. 2018, vol. 6, no. 2, pp. 439-442. DOI: 10.22378/2313-6197.2018-6-2.439-442

On May 10-11 2018, the Faculty of Arts of the University of Szeged hosted an annual gathering of scholars dealing with various aspects of the history of the Mongol Empire. This workshop, named The Mongols and the Silk Roads, was organized by István Zimonyi, Szilvia Kovács and Márton Vér, members of the Turkological Research group of MTA-SZTE ("Hungarian Academy of Sciences University of Szeged"). It was conceived as a continuation of two similar events, previously held in Jerusalem (Diplomacy in the Age of Mongol Globalization, or- 
ganized by Francesca Fiaschetti and Marie Favereau in 2016) and Sofia (Mongol Warfare between Steppe and Sown, organized by Boryana Antonova and Konstantin Golev in 2017).

The main goals of this workshop were the reassessment of a role that the international networks of merchants, and their activities along the Silk Roads, played in the Mongol Empire, and their influence on the growth of trans-regional trade and expansion the commercial routes to new regions and the maritime areas. There were eleven participants, from Hungary, United Kingdom, Germany, Bulgaria, Serbia, Israel, China and Japan, who covered a wide range of topics and source materials. Most of the presentations were either directly or indirectly related to the history of the Golden Horde. The working language was English.

On May 10, the event began with the opening speeches of Klára Sándor, Vice dean of the Faculty of Arts, and István Zimonyi. On the same day, the participants of the workshop and wider audience had the opportunity to hear the lecture of István Vásáry, professor emeritus of Eötvös Loránd University, Budapest, and the key speaker of the event. In his lecture The Mongol Period: Heyday of the Silk Roads, Vásáry emphasized hitherto neglected aspects of cultural exchange between eastern and western parts of the Mongol Empire, the development of various Turkic literary languages and dialects in the Mongol period and their role as a medium of communication.

During the second day, the participants presented their contributions in four consecutive sessions. The first speaker was Marie Favereau (Oxford University). Her presentation Money as a Medium of Exchange in the Fourteenth-Century Golden Horde covered various actual topics, from the role of the Jochid elites in the commercial exchanges, adoption of the Islamic coinage system in the Golden Horde, to the monetary reforms of Tokhta, Janibek, and Tokhtamysh. It was followed by Aleksandar Uzelac (Institute of History, Belgrade), whose paper The Jochids and Crimea in the Second Half of the Thirteenth Century dealt with the organization of the Jochid rule in Crimea, delegation of the administrative power at the local level, and the role of this region in the opening of the trade routes during the early Jochid period. The final speaker at the first session was Csaba Göncöl (University of Szeged). In his paper Tolu Bay, Emìr of Khan BerdiBek, he analyzed in detail the historical role of the enigmatic Tolu Bay in the mid-fourteenth century, on the basis of wide range of Turkic, Persian and Russian sources.

István Zimonyi (University of Szeged) opened the second session with another insightful and detailed presentation, titled The Great Town - Men Kermen in "The Secret History of the Mongols". He provided extremely valuable overview of the earlier scholarship concerning the identification of the city of Man Kermen (Mankerman) in this source, and proposed a new and intriguing hypothesis by equating it with Bilär, the capital of the Volga Bulgaria. Next speaker was Konstantin Golev (Institute for Historical Studies of the Bulgarian Academy of Sciences). His presentation The Cuman-Qïpchaqs, the Khwärazmshāhs and the Cities on the Lower Course of Syr Darya revolved around several intriguing issues: the relations of Cumans/Qipchaqs with the Central Asian cities along the lower course of the Syr Darya river - Jand and Signak, their inclusion into the socio-political structure of the eastern Qïpchaq tribes and the effects of the Khwārazmian expansion over the Qïpchaq presence in these cities. The session was concluded by Qiu Yihao 
(Fudan University, Shanghai) with the topic: Postal System, Rabat (Inns) and Caravansaries on the Post-Mongol Silk Road. Accounts of the Routes linked the Ming Empire and Timurid Central Asia. He provided a valuable preliminary survey of some recently discovered sixteenth century geographical sources, including "Mongolian Landscape Map", "The Commentary on the Territories and Peoples of the western Regions" and a late edition of "Jurjānī's Book of Roads and Kingdoms".

The third session was opened by Francesca Fiaschetti (Hebrew University of Jerusalem). Her presentation Mongols at Sea: the maritime Silk Roads and midYuan China dealt with the maritime engagement of the Yuan dynasty and its longterm impact on the subsequent economic and political development of Southeast Asia. She also provided a valuable analysis of some lesser known and understudied Chinese sources concerning these topics. The next speaker was Márton Vér (Berlin-Brandenburg Academy of Sciences and Humanities), who in his contribution The ortok-Merchants in the Old Uyghur documents, discussed various types of partnership between the Central Asian merchants and the empire building nomads of Central Eurasia. Additionally, he provided insight into the Old Uyghur documents that can be connected to ortok-merchants and associations, particularly emphasizing several so far unpublished texts.

At the last session, Yoichi Isahaya (JSPS/Rikkyô University) presented his paper Bìrün's Revival along the Mongol Silk Roads. As the title suggests, he dealt with the "revival" of Bīrūnī's works in the Mongol-ruled Iran during the Ilkhanate era, but also turned the attention toward the eastern part of the Mongol empire, by demonstrating how the so-called al-Qanūn al-Mas 'ūdì was transmitted into the intellectual sphere of the Yuan dynasty. The working part of the workshop was concluded by Szilvia Kovács (University of Szeged), whose presentation was titled Friars on the road(s) in the Mongol world $\left(13^{\text {th }}-14^{\text {th }}\right.$ centuries $)$. In her focus were several neglected issues surrounding the missions of the Franciscans John of Plano Carpini, William of Rubruck and their successors, including the choice of their routes and their sources of information, how the missionaries kept the contacts with the West on their travels, and how valuable are their reports with respect to the Mongol postal system (yam).

All presentations were followed by long, exhaustive and fruitful discussions. In his closing words, Zimonyi announced that the presented materials will be published in 2019, in one of the volumes of the internationally recognized journal "Acta Orientalia Academiae Hungaricae". During the event and after its official conclusion the participants had the opportunity to enjoy the proverbial hospitality of their hosts from the Turkological Research group of MTA-SZTE and the Faculty of Arts in Szeged.

About the author: Aleksandar Uzelac - Ph.D. (History), Research Associate, The Institute of History Belgrade, ORCID: http://orcid.org/0000-0003-0626-2928 (36/II, Kneza Mihaila Str., Belgrade 11000, Serbia). E-mail: aleksandar.uzelac@iib.ac.rs 


\title{
СЕМИНАР «МОНГОЛЫ И ШЕЛКОВЫЕ ПУТИ» \\ (10-11 МАЯ 2018 Г., ГУМАНИТАРНЫЙ ФАКУЛЬТЕТ, УНИВЕРСИТЕТ СЕГЕДА)
}

\author{
Александар Узелац \\ Институт истории (Белград) \\ Белград, Сербия \\ aleksandar.uzelac@iib.ac.rs
}

10-11 мая 2018 г. Гуманитарный факультет университета Сегеда провел очередную ежегодную встречу исследователей, изучающих историю Монгольской империи. Мероприятие было организовано несколькими членами Тюркологической исследовательской группы MTA-SZTE («Академия наук Венгрии - университет Сегеда»). Его главная цель заключалась в переоценке той роли международных сетей торговцев и их деятельности на протяжении Шелковых путей, которую они играли в Монгольской империи. В мероприятии приняли участие 11 участников из Венгрии, Великобритании, Германии, Болгарии, Сербии, Израиля, Китая и Японии, которые охватывали широкий круг тематик и материалов источников. Рабочим языком семинара был английский.

В первый день Иштван Вашари, главный докладчик мероприятия и почетный профессор университета имени Лоранда Этвёша, провел свою лекцию «Монгольский период: расцвет Шелковых путей». На следующий день были представлены доклады других участников в рамках четырех сессий, в завершении каждой из которых последовала продолжительная, исчерпывающая и плодотворная дискуссия. Представленные доклады будут опубликованы в 2019 г. в одном из томов международно признанного журнала «Acta Orientalia Academiae Hungaricae».

Ключевые слова: Монгольская империя, Шелковые пути, Золотая Орда, международный семинар, Тюркологическая исследовательская группа MTA-SZTE

Для цитирования: Uzelac A. Workshop: The Mongols and the Silk Roads (May 1011, 2018, Faculty of Arts, University of Szeged) // Золотоордынское обозрение. 2018. T. 6, № 2. C. 439-442. DOI: 10.22378/2313-6197.2018-6-2.439-442

Сведения об авторе: Александар Узелац - Ph.D. (история), научный сотрудник, Институт истории (Белград), ORCID: http://orcid.org/0000-0003-0626-2928 (11000, ул. Кнеза Михаила, 36/II, Белград, Сербия). E-mail: aleksandar.uzelac@iib.ac.rs 